\title{
Optoacoustic Imaging in Inflammation
}

\author{
Adrian P. Regensburger ${ }^{1, \dagger}{ }^{\text {, Emma Brown }}{ }^{2,3, \dagger}$, Gerhard Krönke ${ }^{4}$, Maximilian J. Waldner ${ }^{5}$ \\ and Ferdinand Knieling ${ }^{1, *(D)}$
}

1 Department of Pediatrics and Adolescent Medicine, University Hospital Erlangen, Friedrich-Alexander-Universität (FAU) Erlangen-Nürnberg, Loschgestr. 15, D-91054 Erlangen, Germany; adrian.regensburger@uk-erlangen.de

2 Department of Physics, University of Cambridge, JJ Thomson Avenue, Cambridge CB3 OHE, UK; emma.brown@cruk.cam.ac.uk

3 Cancer Research UK Cambridge Institute, University of Cambridge, Li Ka Shing Centre, Robinson Way, Cambridge CB2 ORE, UK

4 Department of Medicine 3, University Hospital Erlangen, Friedrich-Alexander-Universität (FAU) Erlangen-Nürnberg, Ulmenweg 18, D-91054 Erlangen, Germany; gerhard.kroenke@uk-erlangen.de

5 Department of Medicine 1, University Hospital Erlangen, Friedrich-Alexander-Universität (FAU) Erlangen-Nürnberg, Ulmenweg 18, D-91054 Erlangen, Germany; maximilian.waldner@uk-erlangen.de

* Correspondence: ferdinand.knieling@uk-erlangen.de; Tel.: +49-9131-8533-118

+ These authors contributed equally.

Citation: Regensburger, A.P.; Brown, E.; Krönke, G.; Waldner, M.J.; Knieling, F. Optoacoustic Imaging in Inflammation. Biomedicines 2021, 9 , 483. https://doi.org/10.3390/ biomedicines 9050483

Academic Editor: Moritz Wildgruber

Received: 19 March 2021

Accepted: 21 April 2021

Published: 28 April 2021

Publisher's Note: MDPI stays neutral with regard to jurisdictional claims in published maps and institutional affiliations.

Copyright: (c) 2021 by the authors. Licensee MDPI, Basel, Switzerland. This article is an open access article distributed under the terms and conditions of the Creative Commons Attribution (CC BY) license (https:// creativecommons.org/licenses/by/ $4.0 /)$.

\begin{abstract}
Optoacoustic or photoacoustic imaging (OAI/PAI) is a technology which enables noninvasive visualization of laser-illuminated tissue by the detection of acoustic signals. The combination of "light in" and "sound out" offers unprecedented scalability with a high penetration depth and resolution. The wide range of biomedical applications makes this technology a versatile tool for preclinical and clinical research. Particularly when imaging inflammation, the technology offers advantages over current clinical methods to diagnose, stage, and monitor physiological and pathophysiological processes. This review discusses the clinical perspective of using OAI in the context of imaging inflammation as well as in current and emerging translational applications.
\end{abstract}

Keywords: optoacoustics; photoacoustics; imaging inflammation; MSOT; RSOM; PAI; acute inflammation; chronic inflammation; molecular imaging

\section{Introduction}

The typical constellation of acute inflammation encompasses four cardinal signs: reddening, local warming, swelling, and pain. On a smaller scale, inflammation presents a reaction to local damage or an infection resulting in a short ischemic phase followed by hyperemia of the local vasculature, remodeling of the connective tissue, and invasion of inflammatory cells [1]. The entire process is well-conserved and can be triggered by multiple stimuli including allergens, antimicrobial pathogens, injury, burns, wounds, or chemical irritants. If the process is not resolved, ongoing inflammation leads to chronic tissue damage and remodeling resulting in diseases such as cancer, arthritis, obesity, diabetes, and neurodegeneration $[2,3]$. The ability to visualize these processes non-invasively in vivo using molecular imaging modalities has fostered our understanding of the underlying pathophysiology [4] and aids the development of personalized drug regimens [5].

This review discusses the unique ability and scalability of optoacoustic or photoacoustic imaging (OAI/PAI) to visualize, monitor, and understand the molecular mechanisms of inflammation. OAI encompasses a set of heterogenous optical imaging technologies utilizing the photoacoustic effect. Based on the observation of Alexander Graham Bell that there is formation of sound waves following light absorption [6], the principle has been rediscovered and used to develop imaging approaches [7]. In OAI, optoacoustic contrast arises when the light is absorbed by tissue molecules and converted into acoustic pressure waves, which can be recorded and formed into optoacoustic images [8]. 
Due to their unique absorption characteristics, endogenous molecules such as deoxyhemoglobin, oxyhemoglobin, collagen, lipids, and melanin enable OAI in the near-infrared (NIR) range [8,9] (Figure 1). In the future, targeted exogenous probes or contrast agents may further enrich the clinical capability of this technology by specifically labeling target molecules or cells for more personalized imaging approaches [6,10-13]. OAI is able to detect a broad range of endogenous and exogenous molecules within a single imaging modality whilst maintaining high spatial resolution at greater depths compared to optical imaging, due to the detection of ultrasound (US) waves, which scatter less in tissue than light $[7,14]$. The non-invasive nature of OAI will allow broad application to both experimental and clinical settings without interfering with biological processes. This review briefly describes the scalability of OAI and its current and potential ability to image inflammatory conditions from a clinical perspective, with regard to different organ systems as follows: cardiovascular, dermatologic, gastrointestinal, musculoskeletal, (neuro-)degenerative, kidney, and gynecologic diseases.

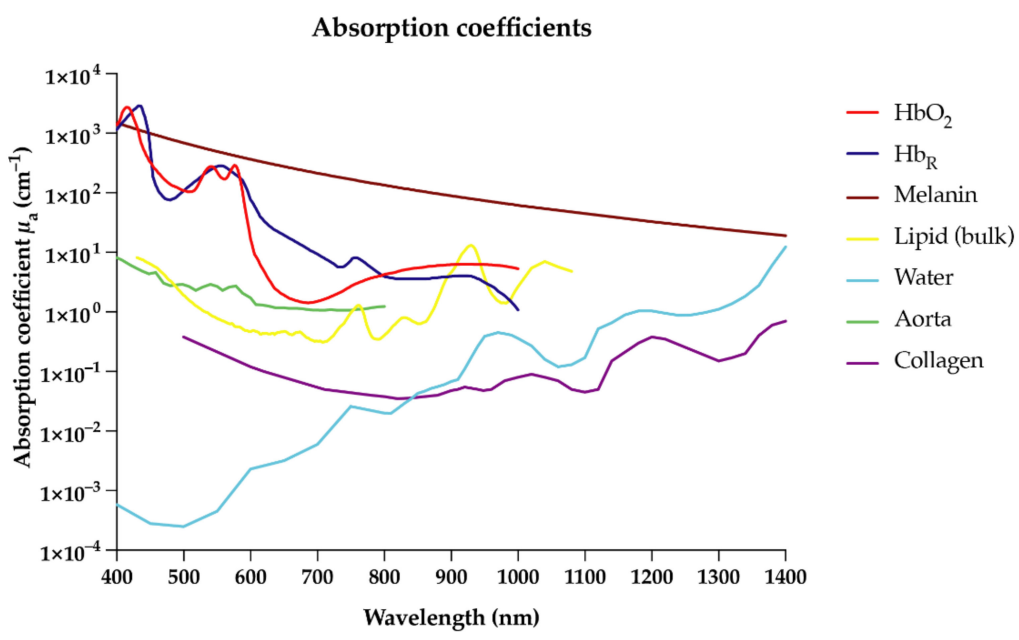

Figure 1. Absorption coefficients $\left(\mu_{\mathrm{a}}\right.$ in $\mathrm{cm}^{-1}$ ) versus wavelength (in $\mathrm{nm}$ ) for different optoacoustic imaging molecules and tissue. Spectra were derived from existing data as indicated: melanin (https://omlc.org/spectra/melanin/mua.html as derived from [15-18]), oxy- $\left(\mathrm{HbO}_{2}\right)$ and deoxyhemoglobin $\left(\mathrm{Hb}_{\mathrm{R}}\right)$ (https://omlc.org/spectra/hemoglobin/summary.html), (bulk) lipid (https:/ / omlc.org/spectra/fat/fat.txt as derived from [19]), water (https:/ / omlc.org/spectra/water/ data/hale73.txt derived from [20]), aorta tissue (https://omlc.org/spectra/aorta/oraevsky_a.txt derived from [21]), and collagen (extracted from [22]). All databases accessed on 9 April 2021.

\section{Optoacoustic Imaging across Scales}

A major advantage of OAI is its scalability; OAI can be performed over a wide range of depths and resolutions enabling molecular imaging across scales and increasing its applicability both experimentally and clinically $[23,24]$. While most imaging setups must adhere to the maximum permissible exposure (MPE) for the use of lasers in medicine as set by American National Standards Institute (ANSI) [25], OAI does not expose subjects to the risks associated with ionizing radiation.

While the first systems were developed as experimental imaging modalities for higher magnification and animal imaging, they have advanced to preclinical and clinical approaches that are mostly classified as microscopic, mesoscopic, or macroscopic/tomographic techniques (Table 1) [26-28]. Similar OAI technologies can deliver very different imaging information; the resolution scales linearly with penetration depth, so while optical resolution photoacoustic microscopy (OR-PAM) achieves less penetration depth but high lateral and spatial resolution of up to $1 \mu \mathrm{m}$ by tight optical focusing, acoustic resolution photoacoustic microscopy (AR-PAM) has limited lateral and spatial resolution by loose acoustic focusing but a penetration depth up to several centimeters [29-32]. Optoacoustic mesoscopy (OPAM) is a modality which bridges the gap between microscopy and macroscopy, with 
acoustic resolution and wide bandwidth US detection for imaging volumes up to several millimeters in depth [33]. For preclinical imaging, ring detectors can be used to utilize loose acoustic focusing for the acquisition of whole-body data sets from living mice within 15-30 min [34-36]. In general, in acoustic resolution methods, the resolution of the system is determined by the acoustic detection components, whereas in optical resolution methods, the resolution is determined by the properties of the excitation light [37].

Table 1. Optoacoustic imaging (OAI) technologies across scales (US = ultrasound, NIR = near-infrared range, exNIR = extended near-infrared range).

\begin{tabular}{ccccccc}
\hline Technique & Resolution & Penetration Depth & Laser Source & Focus & References \\
\hline Microscopy & $\begin{array}{c}\text { Optical } \\
\text { resolution } \\
\text { Acoustic } \\
\text { resolution }\end{array}$ & $\begin{array}{c}\sim 1 \mu \mathrm{m} \\
\sim 85 \mu \mathrm{m}\end{array}$ & $>1 \mathrm{~mm}$ & Visible/NIR & US $<$ Optical & [30] \\
\hline Mesoscopy & & $\sim 10 \mu \mathrm{m}$ & $1-4 \mathrm{~mm}$ & Visible & US $>$ Optical & [33] \\
\hline $\begin{array}{l}\text { Macroscopy/ } \\
\text { Tomography }\end{array}$ & $\sim 250 \mu \mathrm{m}$ & $2-5 \mathrm{~cm}$ & NIR/exNIR & None & [36] \\
\hline
\end{tabular}

\section{Acute and Chronic Inflammation}

Inflammation is a broad topic impacting both physiological and pathophysiological processes in the human body [38]. Inflammation can not only promote neurodegeneration [39], metabolic disorders [40], allergic inflammation [41], or cancer [42], it is also required for the well-coordinated process of tissue repair and healing [43]. Whether the inflammation is initiated by thermal injury, trauma, infection, or other stimuli, OAI holds promise to visualize inflammation at different steps between the acute and chronic stages derived from cellular, vascular, or extracellular responses [44,45]. OAI has a unique ability to image many of the endogenous molecules present in the inflammatory process, such as hemoglobin and collagen (Figure 1), as well as label other inflammatory cells or molecules using exogenous contrast agents $[6,9,27,36,46]$. A brief overview of the inflammatory process and possible imaging targets is given in Figure 2.

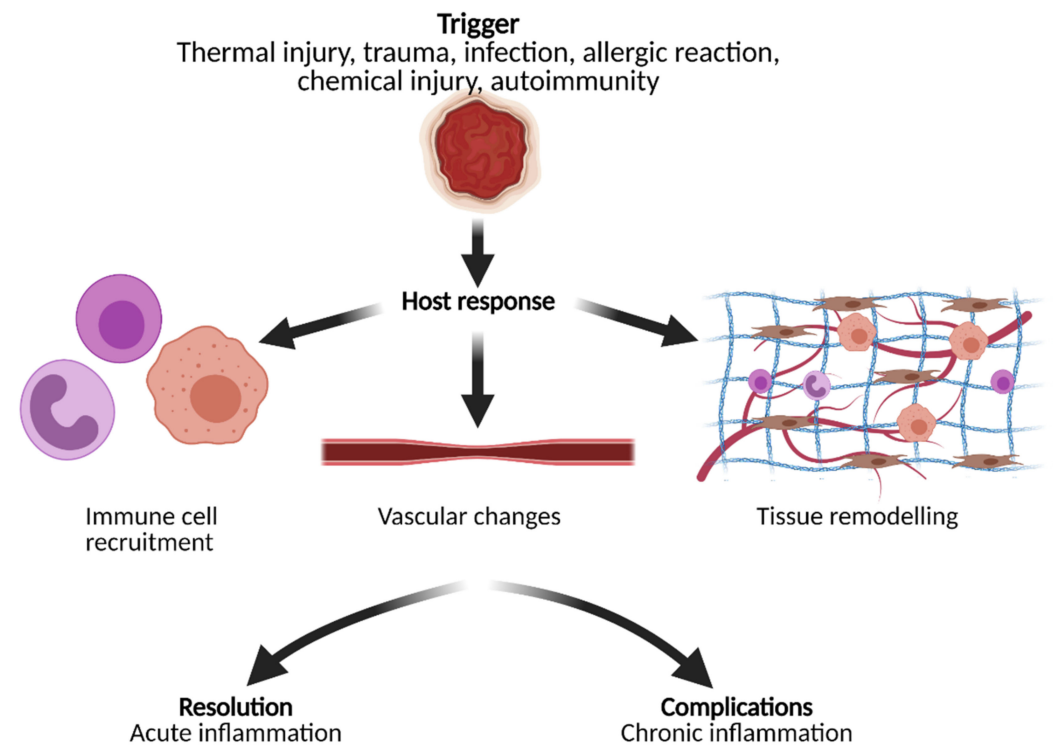

Figure 2. Inflammation is a multistep process triggered by a variety of causes and agents. This results in acute and/or chronic inflammation, which leads to host response in terms of cell recruitment, adaptions of the vasculature, and changes of the tissue composition and extracellular matrix. All of these aspects pose possible targets for opto-/photoacoustic imaging. Figure created with BioRender.com. 


\section{Optoacoustic Imaging of Inflammation: Applications}

The following section discusses translational and clinically relevant applications of OAI inflammation imaging. Table 2 gives an overview of selected studies.

Table 2. Selected inflammatory diseases studied with OAI. ICG = indocyanine green, NET = near-infrared erythrocytederived transducers, NP = nanoparticle, VEGF = Vascular endothelial growth factor, TNF $\alpha=$ tumor necrosis factor- $\alpha$.

\begin{tabular}{|c|c|c|c|c|}
\hline Diseases & Condition & Stage & Target/Contrast & Reference \\
\hline \multirow{8}{*}{ Cardiovascular } & Atherosclerosis & Preclinical & Lipid & [47-55] \\
\hline & Atherosclerosis & Preclinical & CD36 targeted NP & [56] \\
\hline & Atherosclerosis & Preclinical & ICG loaded NETs & [57] \\
\hline & Atherosclerosis & Preclinical & Gold nanoparticles & [58] \\
\hline & Foot vasculature & Clinical & Hemoglobin & [59] \\
\hline & Vascular malformations & Clinical & Hemoglobin & {$[60]$} \\
\hline & Carotid arteries & Clinical & Hemoglobin & {$[61]$} \\
\hline & Peripheral artery disease & Clinical & Hemoglobin & {$[62]$} \\
\hline \multirow{6}{*}{ Dermatologic } & Thermal injuries & Preclinical & Hemoglobin & [63-65] \\
\hline & $\begin{array}{l}\text { LPS-induced wound } \\
\text { inflammation }\end{array}$ & Preclinical & Hemoglobin & [66] \\
\hline & Bacterial wound infection & Preclinical & Targeted sugars & {$[67,68]$} \\
\hline & Skin microvasculature, layers & Clinical & Hemoglobin & {$[69,70]$} \\
\hline & Psoriasis & Clinical & Hemoglobin & {$[71,72]$} \\
\hline & Atopic dermatitis & Clinical & Hemoglobin & {$[73,74]$} \\
\hline \multirow{8}{*}{ Gastrointestinal } & Acute liver damage & Preclinical & ICG Perfusion & [75] \\
\hline & Acute liver damage & Preclinical & $\begin{array}{c}\text { Probes, NO, H2S and leucine } \\
\text { aminopeptidase }\end{array}$ & [76-78] \\
\hline & Liver fibrosis & Preclinical & Collagen & [79] \\
\hline & Intestinal strictures & Preclinical & Collagen & {$[80,81]$} \\
\hline & Intestinal inflammation & Preclinical & Hemoglobin & {$[82,83]$} \\
\hline & Image-guided surgery & Preclinical & Hemoglobin & [82] \\
\hline & $\begin{array}{l}\text { Intestinal vasculature and } \\
\text { lymphatic vessels }\end{array}$ & Preclinical & Hemoglobin, Evans blue dye & [83] \\
\hline & Intestinal inflammation & Clinical & Hemoglobin & {$[84,85]$} \\
\hline \multirow{4}{*}{ Musculoskeletal } & Arthritis & Preclinical & $\begin{array}{l}\text { NP: targeting L-selectin/P-selectin, } \\
\text { TNF } \alpha, \text { VEGF }\end{array}$ & [86-88] \\
\hline & Rheumatoid arthritis & Clinical & Hemoglobin & [89] \\
\hline & Enthesitis & Clinical & Hemoglobin & [90] \\
\hline & Systemic sclerosis & Clinical & Hemoglobin & {$[60,91]$} \\
\hline \multirow{3}{*}{ Neurodegenerative } & Alzheimer's diseases & Preclinical & CDnir7 & [92] \\
\hline & Cerebrovascular damage & Preclinical & Hemoglobin & [93] \\
\hline & Muscular dystrophy & Clinical & Collagen & [94] \\
\hline \multirow{3}{*}{ Kidney } & Organ perfusion & Preclinical & ICG Perfusion & [95] \\
\hline & Acute injury & Preclinical & NP & [96] \\
\hline & Organ transplant & Clinical & Collagen & [97] \\
\hline \multirow{2}{*}{ Gynecologic } & Preeclampsia & Preclinical & Hemoglobin & {$[98,99]$} \\
\hline & Preeclampsia & Preclinical & ICG targeting FR $\alpha$ & [100] \\
\hline
\end{tabular}




\subsection{Cardiovascular Diseases}

A traditional domain for OAI has been the imaging of strong endogenous molecules such as hemoglobin, which is a dominant absorber in the near-infrared window I (NIR-I, 600-950 nm, Figure 1) [26]. Using multi-wavelength approaches, OAI systems are capable of distinguishing deoxygenated hemoglobin $\left(\mathrm{Hb}_{\mathrm{R}}\right.$, which is the dominant absorber at $700 \mathrm{~nm})$ and oxygenated hemoglobin $\left(\mathrm{HbO}_{2}\right.$, which is the dominant absorber at $\left.850 \mathrm{~nm}\right)$. Total hemoglobin $\left(\mathrm{Hb}_{\mathrm{T}}=\mathrm{Hb}_{\mathrm{R}}+\mathrm{HbO}_{2}\right)$ can be calculated as well as oxygenation levels (ratio of $\mathrm{HbO}_{2}$ to $\mathrm{Hb}_{\mathrm{T}}$ ) [101]. In the visible and NIR-spectrum, there are also multiple isosbestic points $(390,422,452,500,530,545,570,584$, and $797 \mathrm{~nm})$, where signals reflect total hemoglobin $\left(\mathrm{Hb}_{\mathrm{T}}\right)$, regardless of the hemoglobin oxygenation level [31,102,103]. Owing to this capability, OAI has been widely used to visualize blood vessels and microcirculation, and to measure blood oxygenation levels, both experimentally in multiple organs $[93,104]$ and clinically in patients [105]. Additionally, OAI has the potential to image blood flow velocity, although this has proved challenging at clinically relevant depths due to poor velocity signal-to-noise ratio [106-108]. Galanzha et al. demonstrated that a photoacoustic system is capable of monitoring multiple blood rheology parameters, such as red blood cell (RBC) aggregation, deformability, shape, intracellular hemoglobin distribution, individual cell velocity, hematocrit, and shear rate [106]. It could also enable diagnostics of infectious pathogens, such as bacteria, viruses, fungi, protozoa, parasites, and helminthes, or endogenous cells such as metastatic, infected, inflamed, stem, and dendritic cells $[109,110]$.

When imaging the circulatory system in the clinic, a hand-held OAI device with a 128-element transducer array at a center frequency of $8 \mathrm{MHz}$ was capable of depicting major blood vessels and microvasculature together with information about hemoglobin oxygen saturation and pulsation [59]. Similar systems demonstrated the ability to resolve vessels as small as $100 \mu \mathrm{m}$ in diameter and within $1 \mathrm{~cm}$ depth, which could aid in accurately diagnosing vascular malformations [60]. Further studies were performed for mapping human carotid arteries [61] and monitoring altered hemoglobin signals and oxygenation in patients with peripheral artery disease [62]. These macroscopic approaches to visualize and monitor the human circulatory system using OAI could be translated to detect inflammatory hyperemia in the future.

OA cardiovascular imaging to date has mostly focused on detecting atherosclerosis and related diseases. While immune cells dominate early atherosclerotic lesions [111], developed atherosclerotic lesions, i.e., atheromata, are asymmetric focal thickenings of the innermost layer of an artery, consisting of inflammatory cells, connective-tissue, lipids, and debris [51,112].

In order to visualize these chronic inflammatory processes, imaging of chronic lipid deposition via OAI was proposed as an imaging biomarker to detect thromboembolism, and subsequently, to monitor the risk of stroke and myocardial infarction. Following this idea, Sangha et al. used a hybrid US/OAI system with illumination in the extended NIR range $(1210 \mathrm{~nm})$ to visualize the differences in lipid accumulation in murine periaortic fat according to gender, genotype, or age [51]. A more recent study described longitudinal dynamics of murine vascular remodeling as well as intraplaque hematoma and lipid deposition in a murine model of atherosclerosis using hybrid US/OAI at $1100 \mathrm{~nm}$ and $1210 \mathrm{~nm}$ [52].

In contrast to these transabdominal imaging approaches described above, several studies have also utilized catheter-based approaches ex vivo [47,53,54], in animal models $[48,55]$ or human samples $[49,50]$, with laser illumination around $930 \mathrm{~nm}$ for detecting the peak absorption of lipids in the first NIR window (Figure 1). Other studies aimed to increase the specificity of OAI for identification of carotid atherosclerosis by targeted approaches. An example is a study which used CD36-labeled semiconducting polymer nanoparticles in combination with OAI to identify the extent of the inflammation of carotid atherosclerosis in mice [56]. CD36 is a membrane glycoprotein present on various inflammatory cell types including monocytes, macrophages, endothelial cells, adipocytes, and platelets, which are all significantly involved in atherogenic processes [113]. Similar to this idea, Xie et al. used near-infrared erythrocyte-derived transducers (NETs), which are 
excited at $800 \mathrm{~nm}$ [57]. This study identified atherosclerosis by vascular occlusion due to accumulation and retention of NETs within the inflammatory lesions [57]. Wang et al. utilized gold nanoparticles, which cause a redshift in the optical absorbance spectra upon aggregation in macrophages of atherosclerotic plaque lesions [58]. In summary, OAI has the potential to deliver both anatomic (vascular) information alongside functional and targeted imaging signals providing biomarkers for increased cardiovascular risk. These studies further demonstrate the flexible use of OAI, which provides imaging insights into a multitude of biomarkers at various anatomical locations, depths, and resolutions. In comparison to traditional cross-sectional imaging modalities, OAI may provide the capabilities to directly visualize lipid-rich plaques, intraplaque hemorrhage or effects of therapeutic agents against plaques, or in-stent inflammation in a non-invasive manner [62]. Cardiovascular diseases are a major cause of mortality, meaning that earlier detection and improved monitoring of disease progression using OAI could have great clinical impact [114].

\subsection{Dermatologic Diseases, Wound and Infection}

In contrast to imaging deep vasculature, in dermal OAI, the trade-off between imaging resolution and depth shifts in favor towards imaging in higher resolution at superficial locations. Therefore, mesoscopic technologies such as raster-scanning optoacoustic mesoscopy (RSOM) are sufficient to visualize several millimeters into the skin and can be used to gain insight into dermatologic diseases [33]. An example of microvascular imaging derived from our own RSOM data is presented in Figure 3. In a preclinical context, dual-wavelength ( $532 \mathrm{~nm}$ and $559 \mathrm{~nm}$ ) OAI was used to monitor the reperfusion of blood vessels and oxygen saturation changes in both arteries and veins in mouse ears to classify ischemic and unaffected tissue [115]. In a clinical proof-of-concept study, Berezhnoi et al. showed that RSOM could visualize the dilation of individual vessels in the skin microvasculature in response to local heating in a region of interest measuring $4 \mathrm{~mm}(\mathrm{x}) \times 2 \mathrm{~mm}(\mathrm{y}) \times 0.75 \mathrm{~mm}(\mathrm{z})$, using a $532 \mathrm{~nm}$ laser, an isosbestic point of hemoglobin [69]. This underlines the possible capability to map local hyperemia in skin as a biomarker for acute vascular response and inflammatory activity. Moreover, RSOM has been shown to visualize capillary loops and the horizontal vascular plexus in the skin, together with the ability to identify different dermal and epidermal layers [70]. This study suggested that a precise localization and visualization of characteristic inflammatory patterns is possible. Given this, the investigators demonstrated that RSOM could detect dilated and contorted blood vessels in the tips of the dermal papillae, as seen in psoriasis [71]. Subsequently, changes in vascularity and visualized hyperemia showed good correlation with clinical scores of disease activity in psoriasis patients [72]. Further studies in atopic dermatitis confirmed that it is possible to score inflammatory activity [73] and response to antibody therapy using RSOM imaging of skin layers and microvasculature [74]. Automation of feature detection and the inclusion of artificial intelligence may even improve objective diagnostics in RSOM and OA clinical imaging [116]. In the future, multi-wavelength RSOM may add additional functional information about other endogenous absorbers such as melanin content or blood oxygenation in different compartments of the human skin [117].

Chronic skin wounds, resulting from diabetes or occlusive peripheral arterial disease, pose a clinically interesting target $[118,119]$. Similar to thermal injuries, which have been previously imaged with optoacoustics [63-65], OAI could help to monitor healing and scar formation, and to guide further surgical interventions. In this regard, Wu et al. demonstrated with macroscopic OAI that burn wounds with a higher severity have greater tissue hypoxia and slower $\mathrm{sO}_{2}$ changes, while microscopic OAI revealed the onset of angiogenesis together with changes in blood vessel density [120]. In the clinic, wound (super-)infection and inflammation can complicate treatment and patient outcomes. Therefore, the effective identification and monitoring of vascular structures and micro-environment changes due to bacterial inflammation is paramount [121]. In this regard, a preclinical study found that lipopolysaccharide (LPS)-induced inflammatory responses of the microvasculature are highly dependent on the applied LPS concentrations [66]. This correlation suggests that 
not only the severity of ischemia, but also the risk for inflammation and infection could be quantified using OAI.
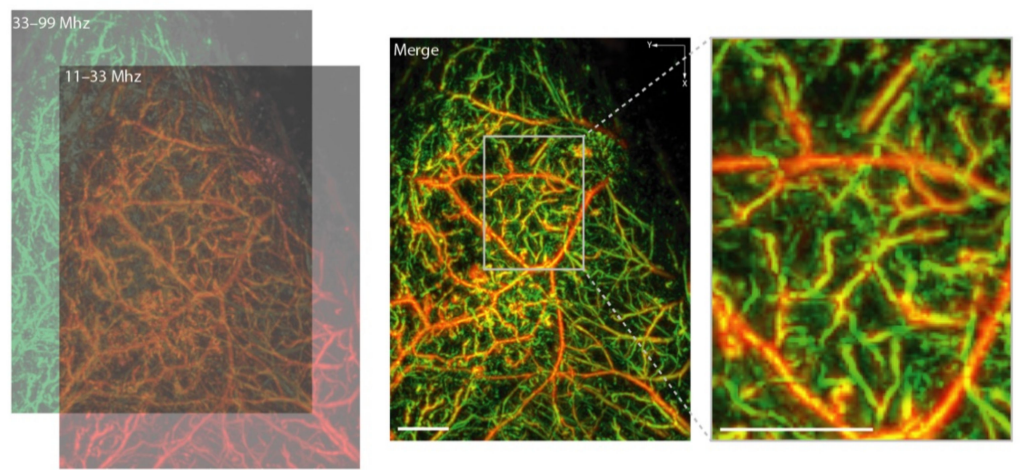

Figure 3. Raster-scanning optoacoustic mesoscopy enables a precise visualization of microvasculature. Depending on the detection frequencies, larger (11-33 MHz, in red) or smaller (33-99 MHz, in green) vessels can be resolved. White square indicates magnified area. Scale bar indicates $1 \mathrm{~mm}$.

Additionally, the proximity of the target structures in skin and wound imaging enables topic application of contrast agents. An elegant study demonstrated the delivery of bacterial-specific imaging probes coupled to complex sugars, which are taken up in larger quantities by microbial organisms [67]. In a comparable approach, an OAI detectable fluorescent derivative of maltotriose (Cy7-1-maltotriose) was used to monitor the effectiveness of antibiotic treatment in E. coli-induced myositis and S. aureus wound infection models [68]. This could enable the rapid identification of bacterial colonization or infection burden earlier than classical cultivation techniques requiring up to several days for diagnosis. This may be a promising approach to also monitor complicated wound infection therapies before aiming for surgical interventions.

Taken together, these studies demonstrate the ability of multi-scale OAI, particularly novel RSOM techniques, to visualize and monitor skin alterations in multiple inflammatory dermatologic diseases. Going forward, OAI may be implemented as a tool to non-invasively monitor pharmacologic interventions and early response to therapy in these patients.

\subsection{Gastrointenstinal Diseases}

Similar to dermal inflammatory processes, mucosal inflammation and gastrointestinal diseases are well characterized by different OAI approaches (Figure 4). In animal models of experimental colitis, increased hemoglobin signals in inflamed intestinal walls were shown [122]. In humans, monitoring hemoglobin levels in intestinal walls with a handheld OAI probe was clinically used to grade disease activity in patients with Crohn's disease (CD) [85]. Increased signal levels of hemoglobin, displaying intestinal hyperemia, correlated well with endoscopic and histologic active disease and could therefore be used to differentiate between active disease and remission in a non-invasive fashion $[84,85]$. The device has since been developed further and a subsequent multicenter trial aims to determine whether the technique can be implemented in the clinical routine (https: / / euphoria2020.eu, last access: 9 April 2021, ClinicalTrials.gov Identifier: NCT04456400). A major application of this device would be the monitoring of anti-inflammatory regimes and simultaneously reducing the need for more invasive procedures, such as endoscopies (Figure 4A). In confocal laser endomicroscopy, fluorescently labeled TNF $\alpha$ [123] and $\alpha 4 \beta 7$ integrin [124] antibodies have been used to provide specific molecular markers of Crohn's disease. Similar OA probes could be used in the future [66] to increase target specificity when monitoring intestinal inflammation.

Intestinal strictures pose a significant burden in chronic inflammatory bowel disease, where patients are often subjected to invasive endoscopic intervention or even surgery $[125,126]$. Yang et al. demonstrated a photoacoustic and ultrasonic dual-mode 
endoscope with the ability to image internal vasculature and lymphatic vessels in vivo [83]. OAI integrated into an acoustic resolution side-view endoscope with multi-wavelength imaging gave insight into hemoglobin and collagen content in intestinal strictures [127]. Even though current conventional cross-sectional imaging techniques are not sufficiently accurate for use in routine clinical practice, transabdominal imaging to quantify the burden of intestinal strictures is highly desirable [128] because it is less invasive. Imaging tissue scars and the proliferation of extracellular components could give insight into chronic inflammation in intestinal strictures. Conventional imaging modalities can identify the strictures but often cannot distinguish whether a stricture is predominantly inflammatory or fibrotic. An internal and external OAI approach was capable of visualizing both in a rat model of Crohn's disease [80]. Even in surgically removed human intestinal stricture specimens, similar changes were found [81]. At mesoscopic levels, imaging of an inflamed colon by assessing the vascular architecture [129] and expansion of broad-absorbing tdTomato expressing activated tumor-associated fibroblasts in colorectal neoplasia was achieved [130].

Another interesting approach awaiting clinical translation is the OAI of acute and chronic liver damage together with liver fibrosis. Liver function assessed by indocyanine green (ICG) clearance and subsequently imaged with optoacoustics was used as a measure for acute acetaminophen-induced hepatotoxicity [75]. Additionally, herbal medicineinduced damage could be graded by a liposomal nanoprobe consisting of a NO responsive dye and a diketopyrrolopyrrole-based conjugated polymer [76]. Similar probes, either for detection of $\mathrm{H}_{2} \mathrm{~S}$ or leucine aminopeptidase, were reported to be detectable by OAI after undergoing absorption redshifting $[77,78]$. The generated prominent optoacoustic signals provided measures for acute liver injury. Another study demonstrated that OAI can provide valuable information about ongoing chronic liver inflammation. In a mouse model of $\mathrm{CCl}_{4}$-induced liver fibrosis, OAI signals significantly increased in fibrotic livers when compared to healthy livers [79]. Interestingly, a single wavelength at $808 \mathrm{~nm}$ seemed to indicate collagen I in large concentrations around fibrotic nodules in murine livers. Even intraoperative imaging, for guiding surgical interventions along major vessels in the liver and pancreas, could be achieved with OAI [82]. A potential application to image changes in the composition of liver tissue is demonstrated in Figure 4B.

A
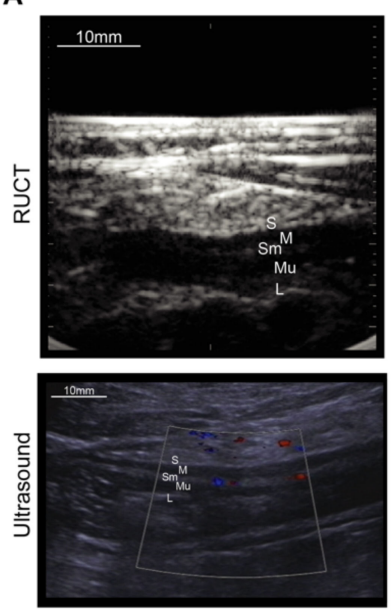
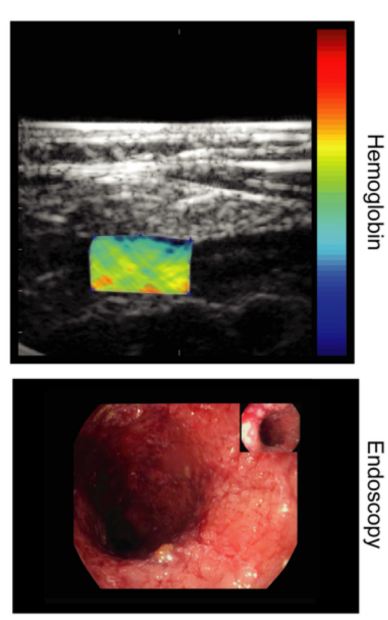

B

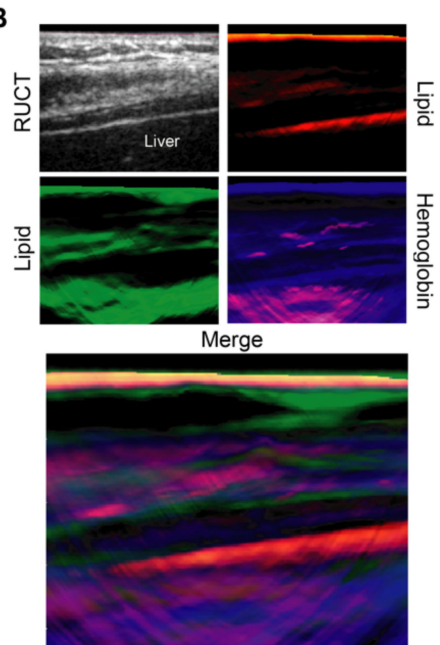

Figure 4. Multispectral optoacoustic tomography (MSOT) of intestinal inflammation using hemoglobin as a surrogate for disease activity. The technique enables hybrid imaging together with B-mode ultrasound imaging (RUCT). (A) MSOT imaging of the liver in humans enabling the generation of signals for different subcellular compounds; (B) $\mathrm{S}=$ serosa, $\mathrm{M}=$ muscularis mucosa, $\mathrm{Sm}=$ submucosa, $\mathrm{Mu}=$ mucosa, $\mathrm{L}=$ lumen, $\mathrm{RUCT}=$ reflectance ultrasound computed tomography. Figure (A) reproduced and modified from [131]. (https:/ / creativecommons.org/licenses/by /4.0/ (accessed on 9 April 2021)). 


\subsection{Musculoskeletal Diseases}

Rheumatoid arthritis (RA) is a chronic autoimmune disease leading to articular destruction associated with co-morbidities in vascular, metabolic, bone, and psychological domains due to tissue remodeling and damage $[132,133]$. In an RA animal model, an L-selectin/P-selectin-labeled contrast agent (a polyanionic dendritic polyglycerol sulfate (dPGS) labeled with an NIR fluorophore), which binds vascular leucocyte adherence proteins, enabled the accurate diagnosis of inflammation in the mouse joints using OAI [86]. Similarly, Fournelle et al. used an antitumor necrosis factor- $\alpha$ (TNF- $\alpha$ ) antibody-coupled to gold nanorods as nanoprobes for confirming the overexpression of TNF- $\alpha$ in arthritic knees [87]. Instead of using nanoparticles, dye-VEGF-antibody-loaded microbubbles enabled multimodal OAI and US imaging of rats with inflammatory arthritis [88].

Additionally in psoriatic arthritis, the imaging of hemoglobin species with OAI may allow for the early detection of inflammation to prevent a delayed diagnosis and the associated complications [89]. Another study found that OAI signals acquired at $850 \mathrm{~nm}$ are sensitive to depicting increased blood volume indicating enthesis inflammation [90]. In the subcutaneous finger tissue of patients with systemic sclerosis (SSc), OAI signals for oxygenated hemoglobin and total hemoglobin reflected chronic microvascular dysfunction as a possible biomarker of disease activity [60]. Together with high-frequency US, OAI may distinguish between early and later forms of SSc by the means of tissue oxygenation and skin thickening [91]. At the mesoscopic level, multi-wavelength RSOM could visualize microvascular structure and oxygenation in murine paws (Figure 5), which may provide further insight into rheumatic diseases with future options for monitoring inflammation and the corresponding therapeutic interventions.
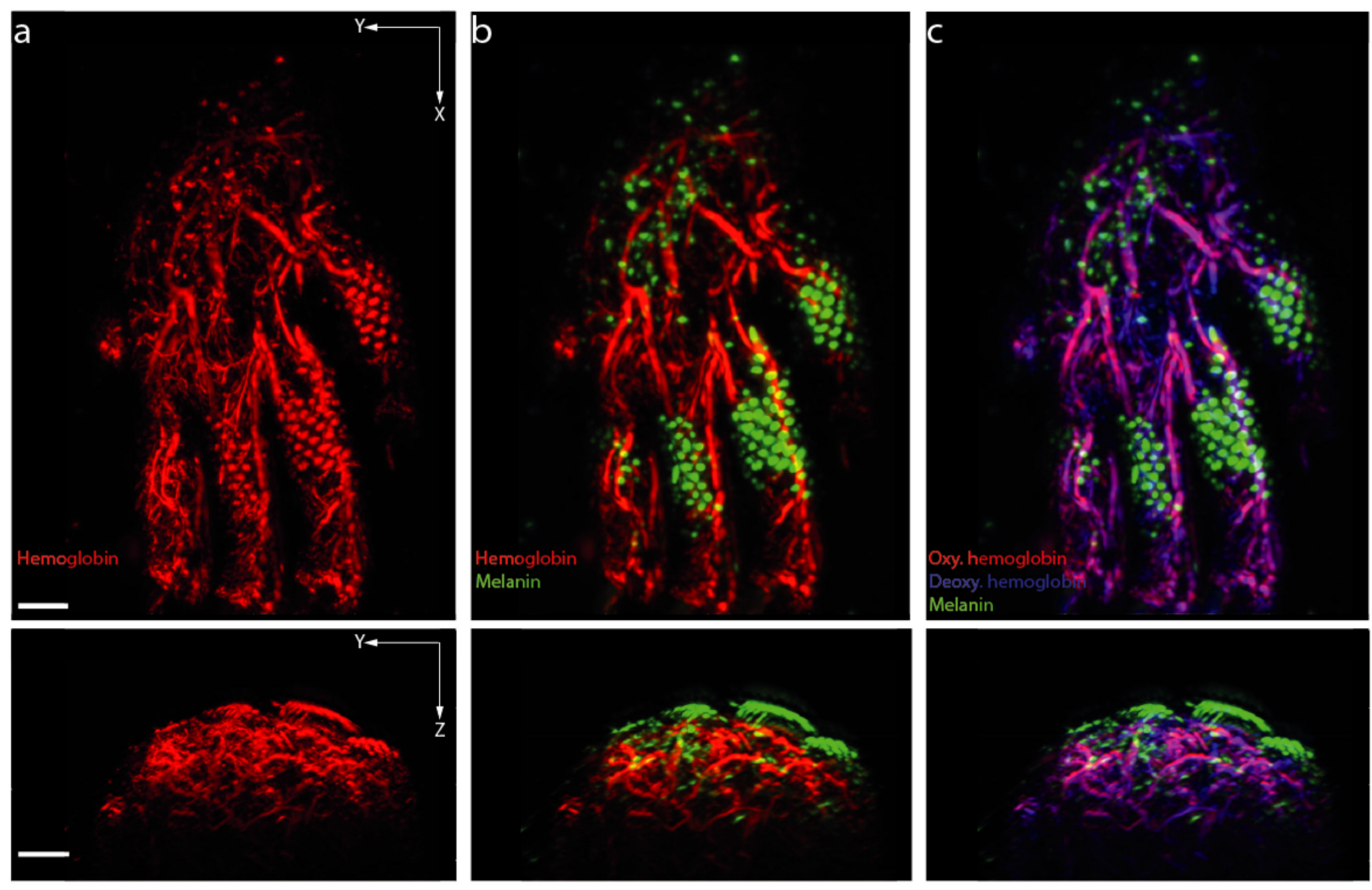

Figure 5. Raster-scanning optoacoustic mesoscopy (RSOM) of murine paw vasculature and the potential imaging readouts for inflammation. (a) Shows the hemoglobin signal representing the vascular network, which can be used to identify changes in blood volume; (b) multi-wavelength illumination enables the separation of melanin and hemoglobin signals; (c) further unmixing enables the visualization of oxygenation status of hemoglobin. Scale bar indicates $1 \mathrm{~mm}$.

\section{5. (Neuro-)Degenerative Diseases}

Optoacoustic microscopy (OAM) and tomographic approaches have been recognized as tools to study animal models of brain diseases [134]. An example of utilizing contrast agents for imaging inflammation in the brain is the development of a CDnir7 probe for 
macrophage uptake [135]. Park et al. used this approach to visualize inflammation related to Alzheimer's disease (AD) changes by visualizing more CDnir7 in the AD mouse cerebral cortex compared to that of normal mice [92]. Another study demonstrated the potential of utilizing dual-wavelength OAI (at $750 \mathrm{~nm}$ and $850 \mathrm{~nm}$ ) to monitor cerebrovascular damage and hypo-oxygenation following brain injury, which is increasingly linked to neurodegenerative disease [93].

A first-in-human pediatric study showed that OAI can be used to assess the molecular composition of muscles in children. The inherited degenerative and fatal Duchenne muscular dystrophy is a disease usually treated by anti-inflammatory steroids. A handheld US/OAI system was able to measure signals between 680 and $1100 \mathrm{~nm}$ correlating with fibrotic content as a novel non-invasive biomarker for disease severity and a potential monitoring tool for novel therapies (Figure 6) [94]. From a clinical perspective, this may open up the possibility of therapeutic monitoring at an earlier age and improve upon the current subjective functional testing or the use of other invasive imaging procedures.
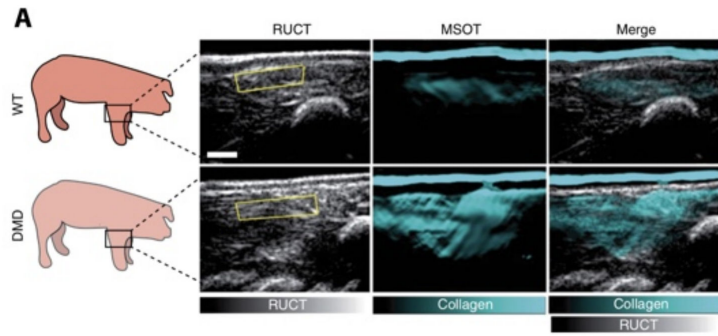

B

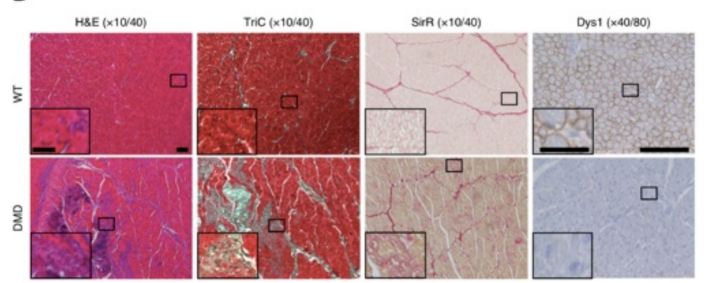

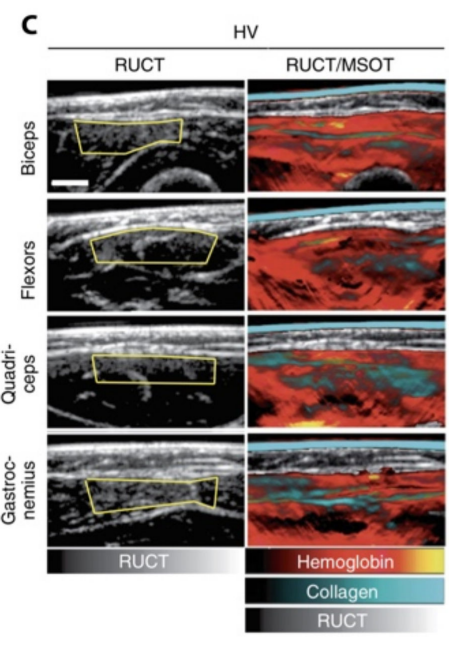

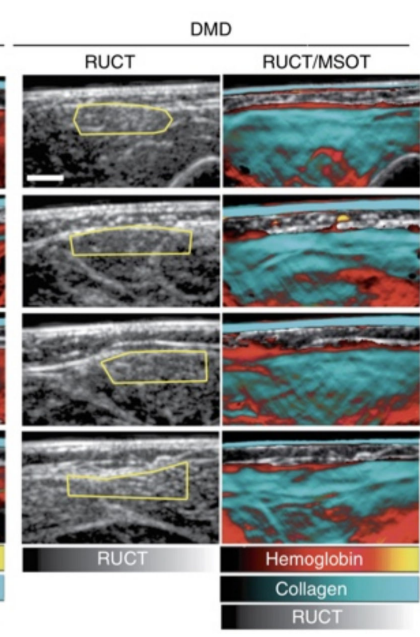

Figure 6. Optoacoustic imaging (OAI) of muscle degeneration in Duchenne muscular dystrophy. (A) Shows signals derived from wild-type (WT) and Duchenne muscular dystrophy (DMD) transgenic pigs; (B) demonstrates ex vivo tissue changes and expansion of extracellular matrix and collagens in diseased tissues as a possible correlate of OAI signals; (C) signals derived from healthy volunteers (HV) and pediatric patients with DMD at different anatomical positions. RUCT and RUCT/MSOT merged images shown. RUCT = reflectance ultrasound computed tomography, MSOT = multispectral optoacoustic tomography. Signals unmixed for hemoglobin and collagen. Figure modified with permission from [94]. This image is not published under the terms of the CC-BY license. For permission to reuse, please see [72].

The technology reliably measures OA signals with minimal error and excellent intraand inter-operator agreement [136]. Similar to gastrointestinal applications, this first-inhuman study frames the idea that it is possible to image late-stage chronic degenerative and inflammatory processes driven by fibrosis with OAI.

\subsection{Kidney Diseases}

In a mouse model, $5.5 \mathrm{~nm}$-sized gold nanoparticle (GNP)-based probes were shown to be able to diagnose acute kidney injury by measuring positive OAI signals between 680 and $970 \mathrm{~nm}$ in the bladder of mice with temporal unilateral ureteral obstruction for $96 \mathrm{~h}$ [96]. This approach may open up a probe-based option for the early detection of inflammatory kidney injury.

Using ICG as a clinically approved contrast agent, preclinical OAI was capable of quantitatively measuring kidney perfusion [95] at $800 \mathrm{~nm}$ (Figure 7). Besides visualizing pharmacokinetic profiles, this approach may also be suitable for determining acute renal injuries and inflammation. In this regard, a more recent study demonstrated how OAI can 
be used to grade organ quality for transplantation by assessing kidney fibrosis as a marker of organ function in mice, pigs, and humans [97]. The authors even demonstrated that OAI can be performed in a human kidney transplantation-like setting, which suggests the emerging potential for clinical translation.
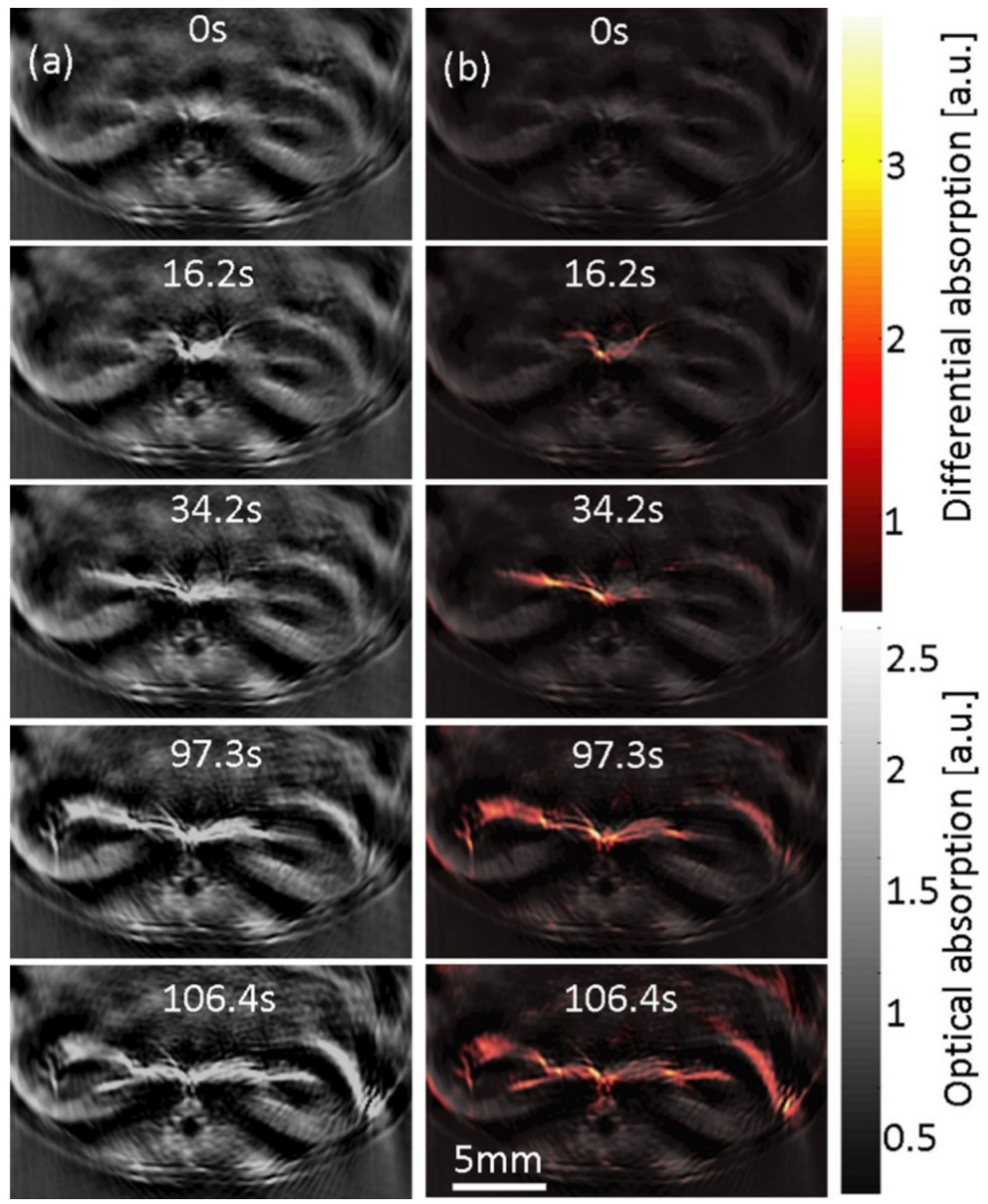

Figure 7. Tomographic optoacoustic imaging of indocyanine perfusion kinetics in murine kidneys. (a) Cross-sectional optoacoustic images over time of mouse kidneys at $800 \mathrm{~nm}$ after ICG injection; (b) the absorption difference with the single-wavelength image before injection to show increased ICG perfusion over time. Adapted with permission from [95]. This image is not published under the terms of the CC-BY license. (C) The Optical Society.

\subsection{Gynaecologic Imaging}

Clinical interventions in early life include monitoring placental function. In preeclampsia, a syndrome of impaired vasculature function, immune modulatory natural killer (NK) cells accumulate in the placenta [137]. OAI could visualize reduced placental perfusion in a rat model of pre-eclampsia [98]. Another interesting approach to monitor placental function was shown by Huda et al., who generated a folate-conjugated ICG contrast agent to image folate accumulation in the placenta [100].

The ability to directly visualize the function of this organ will foster the development of novel therapeutics to treat placental ischemia and halt the progression of pre-eclampsia [99].

\section{Limitations of OAI}

Despite its remarkable potential to image inflammation in a clinical setting, OAI has several limitations. Until now, penetration depths have still been limited to a few centimeters (up to $\sim 7 \mathrm{~cm}$ ), which limits the imaging of organs at depth, especially in 
patients with a high body mass index (BMI). However, not only increased body fat, but also the natural heterogenous fat distribution in different genders is a limiting factor [136]. OA endoscopy approaches may bypass this depth limitation in some scenarios. In addition, patients with increased hair or darker skin (skin type 4 to 6 on the Fitzpatrick scale) present a challenge due to the high level of light absorption by melanin, which will significantly reduce the light energy (fluence) reaching deeper tissue. Comparable problems are seen in animals with melanin expression (e.g., C57BL6 and others), limiting options for in vivo animal models with intact immune systems. The problem of wavelength- and depthdependent decreases in light fluence distribution becomes more pronounced in deep tissues, causing errors in estimating blood oxygen saturation differences [46] in particular. Correcting for spectral distortions of illumination light as it passes through tissue would allow the absolute quantification of optoacoustic molecules, but it remains a significant challenge to apply in vivo and hence is an active area of research in the field $[46,138]$.

A topic currently under investigation is the standardization of OAI measurements, especially in quantitative measurements for clinical applications $[139,140]$. Even though there is evidence for repeatable and stable OAI measurements over time [136], their use is still far from clinical "routine". To aid clinical translation, the clinician would also require more intuitive approaches to interpret optoacoustic images, preferably together with sufficient familiar anatomical information. Therefore, a hybrid imaging approach together with co-registration of (high-resolution) B-mode US signals is highly important $[141,142]$. The use of exogenous contrast agents to specifically label target molecules should be conducted with caution, owing to the possible toxicities associated with their administration [143].

Finally, most of the clinical studies conducted to date have been observational and/or conducted on a limited number of patients. The studies have not impacted the clinical decision-making of the patient. Therefore, the true impact and benefits of using OAI in clinical inflammation imaging need to be assessed in multi-center prospective studies, of which there is one study currently underway in Europe (https:/ / euphoria2020.eu, last access: 9 April 2021, ClinicalTrials.gov Identifier: NCT04456400).

\section{Conclusions}

OAI is an emerging non-invasive imaging modality which has already had significant impact on unravelling the pathophysiology of inflammation in preclinical and clinical scenarios. OAI provides a multi-scale perspective of inflammatory processes, monitoring both structural and functional aspects at various anatomical locations, resolutions, and imaging depths. Besides visualizing strong absorbing hemoglobin, and therefore vascular structure, future approaches will focus on novel endogenous, as well as exogenous, OA compounds.

As shown by the first meaningful clinical studies described here, OAI may be sensitive enough to detect even slight inflammatory changes in tissues, therefore enabling early or even preventive treatment strategies. Despite the first preclinical studies, OAI awaits the translation of novel contrast agents for imaging inflammatory cells or microorganisms [144]. This approach could also enable the targeted delivery of functionalized multimodal and theranostic compounds to abnormal tissues while sparing the other organ systems [145-147]. At the same time, a high signal intensity and a high degree of biodegradation is required when administered in humans [148].

Author Contributions: Conceptualization, F.K.; writing—original draft preparation, F.K.; writingreview and editing, A.P.R., E.B., G.K., and M.J.W.; visualization, F.K.; supervision, F.K. All authors have read and agreed to the published version of the manuscript.

Funding: This research was funded by ELAN Fonds at the University Hospital of the FriedrichAlexander-Universität (FAU) Erlangen-Nürnberg, P055, the Interdisciplinary Center for Clinical Research (IZKF) at the University Hospital of the Friedrich-Alexander-Universität (FAU) ErlangenNürnberg, Clinician Scientist program, Else Kröner-Fresenius-Stiftung, 2018_EKMS.03, European Union's Horizon 2020 research and innovation programme, No. 830965, and Cancer Research UK, C9545/A29580. 
Institutional Review Board Statement: If not otherwise referenced, all images shown from preclinical models were derived from animal experiments approved by the responsible authorities (Institutional Animal Care and Use Committee of the State Government of Middle Franconia, Protocol No. 55-22532-2-507).

Informed Consent Statement: Not applicable.

Data Availability Statement: Not applicable.

Acknowledgments: The present work was performed in (partial) fulfillment of the requirements for obtaining the degree "Dr. rer. biol. hum." for F.K.

Conflicts of Interest: A.P.R., M.J.W., and F.K. are co-inventors, together with iThera Medical GmbH, Munich, Germany, on an EU patent application (EP 19163 304.9) relating to a device and a method for analyzing optoacoustic data, an optoacoustic system, and a computer program. A.P.R. and F.K. received travel support from iThera Medical $\mathrm{GmbH}$, Munich, Germany. A.P.R. reports lecture fees from Sanofi-Aventis Deutschland GmbH, Frankfurt, Germany. F.K. reports lecture fees from Siemens Healthcare $\mathrm{GmbH}$, Erlangen, Germany outside the submitted work. All other authors declare no competing interests.

\section{References}

1. Wilting, J.; Becker, J.; Buttler, K.; Weich, H.A. Lymphatics and inflammation. Curr. Med. Chem. 2009, 16, 4581-4592. [CrossRef] [PubMed]

2. Gupta, S.C.; Kunnumakkara, A.B.; Aggarwal, S.; Aggarwal, B.B. Inflammation, a Double-Edge Sword for Cancer and Other Age-Related Diseases. Front. Immunol. 2018, 9, 2160. [CrossRef]

3. Karin, M.; Clevers, H. Reparative inflammation takes charge of tissue regeneration. Nature 2016, 529, 307-315. [CrossRef] [PubMed]

4. Hammoud, D.A. Molecular Imaging of Inflammation: Current Status. J. Nucl. Med. 2016, 57, 1161-1165. [CrossRef]

5. Willmann, J.K.; van Bruggen, N.; Dinkelborg, L.M.; Gambhir, S.S. Molecular imaging in drug development. Nat. Rev. Drug Discov. 2008, 7, 591-607. [CrossRef]

6. Manohar, S.; Razansky, D. Photoacoustics: A historical review. Adv. Opt. Photon. 2016, 8, 586-617. [CrossRef]

7. Wang, L.V.; Hu, S. Photoacoustic tomography: In vivo imaging from organelles to organs. Science 2012, 335, 1458-1462. [CrossRef] [PubMed]

8. Ntziachristos, V.; Razansky, D. Molecular imaging by means of multispectral optoacoustic tomography (MSOT). Chem. Rev. 2010, 110, 2783-2794. [CrossRef]

9. Tzoumas, S.; Deliolanis, N.; Morscher, S.; Ntziachristos, V. Unmixing Molecular Agents From Absorbing Tissue in Multispectral Optoacoustic Tomography. IEEE Trans. Med. Imaging 2014, 33, 48-60. [CrossRef]

10. Zeng, L.; Ma, G.; Lin, J.; Huang, P. Photoacoustic Probes for Molecular Detection: Recent Advances and Perspectives. Small 2018, 14, e1800782. [CrossRef]

11. Bayer, C.L.; Joshi, P.P.; Emelianov, S.Y. Photoacoustic imaging: A potential tool to detect early indicators of metastasis. Expert Rev. Med. Devices 2013, 10, 125-134. [CrossRef]

12. Zhang, C.; Kimura, R.; Abou-Elkacem, L.; Levi, J.; Xu, L.; Gambhir, S.S. A Cystine Knot Peptide Targeting Integrin alphavbeta6 for Photoacoustic and Fluorescence Imaging of Tumors in Living Subjects. J. Nucl. Med. 2016, 57, 1629-1634. [CrossRef] [PubMed]

13. De la Zerda, A.; Bodapati, S.; Teed, R.; May, S.Y.; Tabakman, S.M.; Liu, Z.; Khuri-Yakub, B.T.; Chen, X.; Dai, H.; Gambhir, S.S. Family of enhanced photoacoustic imaging agents for high-sensitivity and multiplexing studies in living mice. ACS Nano 2012, 6, 4694-4701. [CrossRef]

14. Zackrisson, S.; van de Ven, S.; Gambhir, S.S. Light in and sound out: Emerging translational strategies for photoacoustic imaging. Cancer Res. 2014, 74, 979-1004. [CrossRef] [PubMed]

15. Jacques, S.L.; McAuliffe, D.J. The melanosome: Threshold temperature for explosive vaporization and internal absorption coefficient during pulsed laser irradiation. Photochem. Photobiol. 1991, 53, 769-775. [CrossRef] [PubMed]

16. Jacques, S.; Glickman, R.; Schwartz, J. Internal Absorption Coefficient and Threshold for Pulsed Laser Disruption of Melanosomes Isolated from Retinal Pigment Epithelium; SPIE: Bellingham, WA, USA, 1996; Volume 2681.

17. Sliney, D.H.; Palmisano, W.A. The evaluation of laser hazards. Am. Ind. Hyg. Assoc. J. 1968, 29, 425-431. [CrossRef]

18. Goldman, L. The skin. Arch Environ. Health 1969, 18, 434-436. [CrossRef]

19. Van Veen, R.L.P.; Sterenborg, H.J.C.M.; Pifferi, A.; Torricelli, A.; Cubeddu, R. Determination of VIS-NIR absorption coefficients of mammalian fat, with time- and spatially resolved diffuse reflectance and transmission spectroscopy. In Proceedings of the Biomedical Topical Meeting, Miami Beach, FL, USA, 14 April 2004; p. SF4.

20. Hale, G.M.; Querry, M.R. Optical Constants of Water in the 200-nm to 200-microm Wavelength Region. Appl. Opt. 1973, 12, 555-563. [CrossRef]

21. Oraevsky, A.A.; Jacques, S.L.; Pettit, G.H.; Saidi, I.S.; Tittel, F.K.; Henry, P.D. XeCl laser ablation of atherosclerotic aorta: Optical properties and energy pathways. Lasers Surg. Med. 1992, 12, 585-597. [CrossRef] 
22. Sekar, S.K.; Bargigia, I.; Mora, A.D.; Taroni, P.; Ruggeri, A.; Tosi, A.; Pifferi, A.; Farina, A. Diffuse optical characterization of collagen absorption from 500 to $1700 \mathrm{~nm}$. J. Biomed. Opt. 2017, 22, 15006. [CrossRef]

23. Oraevsky, A.; Jacques, S.; Esenaliev, R.; Tittel, F. Laser-Based Optoacoustic Imaging in Biological Tissues; SPIE: Bellingham, WA, USA, 1994; Volume 2134.

24. Steinberg, I.; Huland, D.M.; Vermesh, O.; Frostig, H.E.; Tummers, W.S.; Gambhir, S.S. Photoacoustic clinical imaging. Photoacoustics 2019, 14, 77-98. [CrossRef]

25. Thomas, R.J.; Rockwell, B.A.; Marshall, W.J.; Aldrich, R.C.; Gorschboth, M.F.; Zimmerman, S.A.; Rockwell, R.J. A procedure for the estimation of intrabeam hazard distances and optical density requirements under the ANSI Z136.1-2000 Standard. J. Laser Appl. 2004, 16, 167-177. [CrossRef]

26. Wang, X.; Xie, X.; Ku, G.; Wang, L.V.; Stoica, G. Noninvasive imaging of hemoglobin concentration and oxygenation in the rat brain using high-resolution photoacoustic tomography. J. Biomed. Opt. 2006, 11, 024015. [CrossRef] [PubMed]

27. Beard, P. Biomedical photoacoustic imaging. Interface Focus 2011, 1, 602-631. [CrossRef]

28. Attia, A.B.E.; Balasundaram, G.; Moothanchery, M.; Dinish, U.S.; Bi, R.; Ntziachristos, V.; Olivo, M. A review of clinical photoacoustic imaging: Current and future trends. Photoacoustics 2019, 16, 100144. [CrossRef]

29. Zhang, H.F.; Maslov, K.; Stoica, G.; Wang, L.V. Functional photoacoustic microscopy for high-resolution and noninvasive in vivo imaging. Nat. Biotechnol. 2006, 24, 848-851. [CrossRef] [PubMed]

30. Park, S.; Lee, C.; Kim, J.; Kim, C. Acoustic resolution photoacoustic microscopy. Biomed. Eng. Lett. 2014, 4, 213-222. [CrossRef]

31. Hu, S.; Wang, L.V. Photoacoustic imaging and characterization of the microvasculature. J. Biomed. Opt. 2010, 15, 011101. [CrossRef]

32. Zhang, H.F.; Maslov, K.; Wang, L.V. In vivo imaging of subcutaneous structures using functional photoacoustic microscopy. Nat. Protoc. 2007, 2, 797-804. [CrossRef] [PubMed]

33. Omar, M.; Aguirre, J.; Ntziachristos, V. Optoacoustic mesoscopy for biomedicine. Nat. Biomed. Eng. 2019. [CrossRef]

34. Razansky, D.; Buehler, A.; Ntziachristos, V. Volumetric real-time multispectral optoacoustic tomography of biomarkers. Nat. Protoc. 2011, 6, 1121-1129. [CrossRef]

35. Brecht, H.P.; Su, R.; Fronheiser, M.; Ermilov, S.A.; Conjusteau, A.; Oraevsky, A.A. Whole-body three-dimensional optoacoustic tomography system for small animals. J. Biomed. Opt. 2009, 14, 064007. [CrossRef] [PubMed]

36. Ntziachristos, V.; Razansky, D. Optical and opto-acoustic imaging. Mol. Imaging Oncol. 2013, 187, 133-150. [CrossRef]

37. Schellenberg, M.W.; Hunt, H.K. Hand-held optoacoustic imaging: A review. Photoacoustics 2018, 11, 14-27. [CrossRef] [PubMed]

38. Stewart, A.G.; Beart, P.M. Inflammation: Maladies, models, mechanisms and molecules. Br. J. Pharm. 2016, 173, 631-634. [CrossRef] [PubMed]

39. Glass, C.K.; Saijo, K.; Winner, B.; Marchetto, M.C.; Gage, F.H. Mechanisms underlying inflammation in neurodegeneration. Cell 2010, 140, 918-934. [CrossRef]

40. Hotamisligil, G.S. Inflammation and metabolic disorders. Nature 2006, 444, 860-867. [CrossRef]

41. Galli, S.J.; Tsai, M.; Piliponsky, A.M. The development of allergic inflammation. Nature 2008, 454, 445-454. [CrossRef]

42. Coussens, L.M.; Werb, Z. Inflammation and cancer. Nature 2002, 420, 860-867. [CrossRef]

43. Eming, S.A.; Wynn, T.A.; Martin, P. Inflammation and metabolism in tissue repair and regeneration. Science 2017, 356, 1026-1030. [CrossRef]

44. Medzhitov, R. Origin and physiological roles of inflammation. Nature 2008, 454, 428-435. [CrossRef]

45. Nathan, C.; Ding, A. Nonresolving inflammation. Cell 2010, 140, 871-882. [CrossRef] [PubMed]

46. Cox, B.; Laufer, J.G.; Arridge, S.R.; Beard, P.C. Quantitative spectroscopic photoacoustic imaging: A review. J. Biomed. Opt. 2012, 17, 061202. [CrossRef]

47. Wang, L.; Lei, P.; Wen, X.; Zhang, P.; Yang, S. Tapered fiber-based intravascular photoacoustic endoscopy for high-resolution and deep-penetration imaging of lipid-rich plaque. Opt. Express 2019, 27, 12832-12840. [CrossRef]

48. Iskander-Rizk, S.; Wu, M.; Springeling, G.; van Beusekom, H.M.M.; Mastik, F.; Te Lintel Hekkert, M.; Beurskens, R.; Hoogendoorn, A.; Hartman, E.M.J.; van der Steen, A.F.W.; et al. In vivo intravascular photoacoustic imaging of plaque lipid in coronary atherosclerosis. EuroIntervention 2019, 15, 452-456. [CrossRef] [PubMed]

49. Hui, J.; Cao, Y.; Zhang, Y.; Kole, A.; Wang, P.; Yu, G.; Eakins, G.; Sturek, M.; Chen, W.; Cheng, J.X. Real-time intravascular photoacoustic-ultrasound imaging of lipid-laden plaque in human coronary artery at 16 frames per second. Sci. Rep. 2017, 7, 1417. [CrossRef] [PubMed]

50. Cao, Y.; Hui, J.; Kole, A.; Wang, P.; Yu, Q.; Chen, W.; Sturek, M.; Cheng, J.X. High-sensitivity intravascular photoacoustic imaging of lipid-laden plaque with a collinear catheter design. Sci. Rep. 2016, 6, 25236. [CrossRef] [PubMed]

51. Sangha, G.S.; Phillips, E.H.; Goergen, C.J. In vivo photoacoustic lipid imaging in mice using the second near-infrared window. Biomed. Opt. Express 2017, 8, 736-742. [CrossRef]

52. Sangha, G.S.; Goergen, C.J. Label-free photoacoustic and ultrasound imaging for murine atherosclerosis characterization. APL Bioeng. 2020, 4, 026102. [CrossRef]

53. Sethuraman, S.; Amirian, J.H.; Litovsky, S.H.; Smalling, R.W.; Emelianov, S.Y. Spectroscopic intravascular photoacoustic imaging to differentiate atherosclerotic plaques. Opt. Express 2008, 16, 3362-3367. [CrossRef]

54. Wang, B.; Karpiouk, A.; Yeager, D.; Amirian, J.; Litovsky, S.; Smalling, R.; Emelianov, S. Intravascular photoacoustic imaging of lipid in atherosclerotic plaques in the presence of luminal blood. Opt. Lett. 2012, 37, 1244-1246. [CrossRef] 
55. Wang, B.; Karpiouk, A.; Yeager, D.; Amirian, J.; Litovsky, S.; Smalling, R.; Emelianov, S. In vivo intravascular ultrasound-guided photoacoustic imaging of lipid in plaques using an animal model of atherosclerosis. Ultrasound Med. Biol. 2012, 38, $2098-2103$. [CrossRef]

56. Xie, Z.; Yang, Y.; He, Y.; Shu, C.; Chen, D.; Zhang, J.; Chen, J.; Liu, C.; Sheng, Z.; Liu, H.; et al. In vivo assessment of inflammation in carotid atherosclerosis by noninvasive photoacoustic imaging. Theranostics 2020, 10, 4694-4704. [CrossRef]

57. Liu, Y.; Hanley, T.; Chen, H.; Long, S.R.; Gambhir, S.S.; Cheng, Z.; Wu, J.C.; Fakhri, G.E.; Anvari, B.; Zaman, R.T. Non-Invasive Photoacoustic Imaging of In Vivo Mice with Erythrocyte Derived Optical Nanoparticles to Detect CAD/MI. Sci. Rep. 2020, 10, 5983. [CrossRef]

58. Wang, B.; Yantsen, E.; Larson, T.; Karpiouk, A.B.; Sethuraman, S.; Su, J.L.; Sokolov, K.; Emelianov, S.Y. Plasmonic intravascular photoacoustic imaging for detection of macrophages in atherosclerotic plaques. Nano Lett. 2009, 9, 2212-2217. [CrossRef] [PubMed]

59. Taruttis, A.; Timmermans, A.C.; Wouters, P.C.; Kacprowicz, M.; van Dam, G.M.; Ntziachristos, V. Optoacoustic Imaging of Human Vasculature: Feasibility by Using a Handheld Probe. Radiology 2016, 281, 256-263. [CrossRef]

60. Masthoff, M.; Helfen, A.; Claussen, J.; Roll, W.; Karlas, A.; Becker, H.; Gabriels, G.; Riess, J.; Heindel, W.; Schafers, M.; et al. Multispectral optoacoustic tomography of systemic sclerosis. J. Biophotonics 2018, 11, e201800155. [CrossRef] [PubMed]

61. Ivankovic, I.; Mercep, E.; Schmedt, C.G.; Dean-Ben, X.L.; Razansky, D. Real-time Volumetric Assessment of the Human Carotid Artery: Handheld Multispectral Optoacoustic Tomography. Radiology 2019, 291, 181325. [CrossRef]

62. Karlas, A.; Fasoula, N.A.; Paul-Yuan, K.; Reber, J.; Kallmayer, M.; Bozhko, D.; Seeger, M.; Eckstein, H.H.; Wildgruber, M.; Ntziachristos, V. Cardiovascular optoacoustics: From mice to men-A review. Photoacoustics 2019, 14, 19-30. [CrossRef] [PubMed]

63. Ida, T.; Iwazaki, H.; Kawaguchi, Y.; Kawauchi, S.; Ohkura, T.; Iwaya, K.; Tsuda, H.; Saitoh, D.; Sato, S.; Iwai, T. Burn depth assessments by photoacoustic imaging and laser Doppler imaging. Wound Repair Regen. 2016, 24, 349-355. [CrossRef] [PubMed]

64. Vionnet, L.; Gateau, J.; Schwarz, M.; Buehler, A.; Ermolayev, V.; Ntziachristos, V. 24-MHz scanner for optoacoustic imaging of skin and burn. IEEE Trans. Med. Imaging 2014, 33, 535-545. [CrossRef]

65. Zhang, H.F.; Maslov, K.; Stoica, G.; Wang, L.V. Imaging acute thermal burns by photoacoustic microscopy. J. Biomed. Opt. 2006, 11, 054033. [CrossRef]

66. Guo, Z.; Li, Z.; Deng, Y.; Chen, S.L. Photoacoustic microscopy for evaluating a lipopolysaccharide-induced inflammation model in mice. J. Biophotonics 2019, 12, e201800251. [CrossRef] [PubMed]

67. Ning, X.; Lee, S.; Wang, Z.; Kim, D.; Stubblefield, B.; Gilbert, E.; Murthy, N. Maltodextrin-based imaging probes detect bacteria in vivo with high sensitivity and specificity. Nat. Mater. 2011, 10, 602-607. [CrossRef] [PubMed]

68. Zlitni, A.; Gowrishankar, G.; Steinberg, I.; Haywood, T.; Sam Gambhir, S. Maltotriose-based probes for fluorescence and photoacoustic imaging of bacterial infections. Nat. Commun. 2020, 11, 1250. [CrossRef] [PubMed]

69. Aguirre, J.; Hindelang, B.; Berezhnoi, A.; Darsow, U.; Lauffer, F.; Eyerich, K.; Biedermann, T.; Ntziachristos, V. Assessing nailfold microvascular structure with ultra-wideband raster-scan optoacoustic mesoscopy. Photoacoustics 2018, 10, 31-37. [CrossRef]

70. Aguirre, J.; Schwarz, M.; Soliman, D.; Buehler, A.; Omar, M.; Ntziachristos, V. Broadband mesoscopic optoacoustic tomography reveals skin layers. Opt. Lett. 2014, 39, 6297-6300. [CrossRef] [PubMed]

71. Boehncke, W.H.; Schon, M.P. Psoriasis. Lancet 2015, 386, 983-994. [CrossRef]

72. Aguirre, J.; Schwarz, M.; Garzorz, N.; Omar, M.; Buehler, A.; Eyerich, K.; Ntziachristos, V. Precision assessment of label-free psoriasis biomarkers with ultra-broadband optoacoustic mesoscopy. Nat. Biomed. Eng. 2017, 1, 0068. [CrossRef]

73. Yew, Y.W.; Dinish, U.S.; Yu Kuan, A.H.; Li, X.; Dev, K.; Ebrahim Attia, A.B.; Bi, R.; Moothanchery, M.; Balasundaram, G.; Aguirre, J.; et al. Raster-scanning optoacoustic mesoscopy (RSOM) imaging as an objective disease severity tool in atopic dermatitis patients. J. Am. Acad. Dermatol. 2020, 84, 1121-1123. [CrossRef]

74. Yew, Y.W.; Dinish, U.S.; Choi, E.C.E.; Bi, R.; Ho, C.J.H.; Dev, K.; Li, X.; Attia, A.B.E.; Wong, M.K.W.; Balasundaram, G.; et al. Investigation of morphological, vascular and biochemical changes in the skin of an atopic dermatitis (AD) patient in response to dupilumab using raster scanning optoacoustic mesoscopy (RSOM) and handheld confocal Raman spectroscopy (CRS). J. Dermatol. Sci. 2019, 95, 123-125. [CrossRef]

75. Brillant, N.; Elmasry, M.; Burton, N.C.; Rodriguez, J.M.; Sharkey, J.W.; Fenwick, S.; Poptani, H.; Kitteringham, N.R.; Goldring, C.E.; Kipar, A.; et al. Dynamic and accurate assessment of acetaminophen-induced hepatotoxicity by integrated photoacoustic imaging and mechanistic biomarkers in vivo. Toxicol. Appl. Pharm. 2017, 332, 64-74. [CrossRef]

76. Wu, Y.; Sun, L.; Zeng, F.; Wu, S. A conjugated-polymer-based ratiometric nanoprobe for evaluating in-vivo hepatotoxicity induced by herbal medicine via MSOT imaging. Photoacoustics 2019, 13, 6-17. [CrossRef]

77. Sun, L.; Wu, Y.; Chen, J.; Zhong, J.; Zeng, F.; Wu, S. A Turn-On Optoacoustic Probe for Imaging Metformin-Induced Upregulation of Hepatic Hydrogen Sulfide and Subsequent Liver Injury. Theranostics 2019, 9, 77-89. [CrossRef] [PubMed]

78. Huang, Y.; Qi, Y.; Zhan, C.; Zeng, F.; Wu, S. Diagnosing Drug-Induced Liver Injury by Multispectral Optoacoustic Tomography and Fluorescence Imaging Using a Leucine-Aminopeptidase-Activated Probe. Anal. Chem. 2019, 91, 8085-8092. [CrossRef] [PubMed]

79. Van den Berg, P.J.; Bansal, R.; Daoudi, K.; Steenbergen, W.; Prakash, J. Preclinical detection of liver fibrosis using dual-modality photoacoustic/ultrasound system. Biomed. Opt. Express 2016, 7, 5081-5091. [CrossRef] [PubMed] 
80. Zhu, Y.; Johnson, L.A.; Huang, Z.; Rubin, J.M.; Yuan, J.; Lei, H.; Ni, J.; Wang, X.; Higgins, P.D.R.; Xu, G. Identifying intestinal fibrosis and inflammation by spectroscopic photoacoustic imaging: An animal study. Biomed. Opt. Express 2018, 9, 1590-1600. [CrossRef] [PubMed]

81. Lei, H.; Johnson, L.A.; Liu, S.; Moons, D.S.; Ma, T.; Zhou, Q.; Rice, M.D.; Ni, J.; Wang, X.; Higgins, P.D.; et al. Characterizing intestinal inflammation and fibrosis in Crohn's disease by photoacoustic imaging: Feasibility study. Biomed. Opt. Express 2016, 7 , 2837-2848. [CrossRef] [PubMed]

82. Kempski, K.M.; Wiacek, A.; Graham, M.; Gonzalez, E.; Goodson, B.; Allman, D.; Palmer, J.; Hou, H.; Beck, S.; He, J.; et al. In vivo photoacoustic imaging of major blood vessels in the pancreas and liver during surgery. J. Biomed. Opt. 2019, 24, 1-12. [CrossRef]

83. Yang, J.M.; Favazza, C.; Chen, R.; Yao, J.; Cai, X.; Maslov, K.; Zhou, Q.; Shung, K.K.; Wang, L.V. Simultaneous functional photoacoustic and ultrasonic endoscopy of internal organs in vivo. Nat. Med. 2012, 18, 1297-1302. [CrossRef] [PubMed]

84. Knieling, F.; Neufert, C.; Hartmann, A.; Claussen, J.; Urich, A.; Egger, C.; Vetter, M.; Fischer, S.; Pfeifer, L.; Hagel, A.; et al. Multispectral Optoacoustic Tomography for Assessment of Crohn's Disease Activity. N. Engl. J. Med. 2017, 376, 1292-1294. [CrossRef] [PubMed]

85. Waldner, M.J.; Knieling, F.; Egger, C.; Morscher, S.; Claussen, J.; Vetter, M.; Kielisch, C.; Fischer, S.; Pfeifer, L.; Hagel, A.; et al. Multispectral Optoacoustic Tomography in Crohn's Disease: Noninvasive Imaging of Disease Activity. Gastroenterology 2016, 151, 238-240. [CrossRef]

86. Beziere, N.; von Schacky, C.; Kosanke, Y.; Kimm, M.; Nunes, A.; Licha, K.; Aichler, M.; Walch, A.; Rummeny, E.J.; Ntziachristos, V.; et al. Optoacoustic imaging and staging of inflammation in a murine model of arthritis. Arthritis Rheumatol. 2014, 66, 2071-2078. [CrossRef]

87. Fournelle, M.; Bost, W.; Tarner, I.H.; Lehmberg, T.; Weiß, E.; Lemor, R.; Dinser, R. Antitumor necrosis factor- $\alpha$ antibody-coupled gold nanorods as nanoprobes for molecular optoacoustic imaging in arthritis. Nanomed. Nanotechnol. Biol. Med. 2012, 8, 346-354. [CrossRef] [PubMed]

88. Zhao, C.; Zhang, R.; Luo, Y.; Liu, S.; Tang, T.; Yang, F.; Zhu, L.; He, X.; Yang, M.; Jiang, Y. Multimodal VEGF-Targeted ContrastEnhanced Ultrasound and Photoacoustic Imaging of Rats with Inflammatory Arthritis: Using Dye-VEGF-Antibody-Loaded Microbubbles. Ultrasound Med. Biol. 2020, 46, 2400-2411. [CrossRef] [PubMed]

89. Hallasch, S.; Giese, N.; Stoffels, I.; Klode, J.; Sondermann, W. Multispectral optoacoustic tomography might be a helpful tool for noninvasive early diagnosis of psoriatic arthritis. Photoacoustics 2021, 21, 100225. [CrossRef]

90. Jo, J.; Xu, G.; Schiopu, E.; Chamberland, D.; Gandikota, G.; Wang, X. Imaging of enthesitis by an LED-based photoacoustic system. J. Biomed. Opt. 2020, 25. [CrossRef]

91. Daoudi, K.; Kersten, B.E.; van den Ende, C.H.M.; van den Hoogen, F.H.J.; Vonk, M.C.; de Korte, C.L. Photoacoustic and high-frequency ultrasound imaging of systemic sclerosis patients. Arthritis Res. 2021, 23, 22. [CrossRef]

92. Park, S.J.; Ho, C.J.H.; Arai, S.; Samanta, A.; Olivo, M.; Chang, Y.T. Visualizing Alzheimer's Disease Mouse Brain with Multispectral Optoacoustic Tomography using a Fluorescent probe, CDnir7. Sci. Rep. 2019, 9, 12052. [CrossRef]

93. Ichkova, A.; Rodriguez-Grande, B.; Zub, E.; Saudi, A.; Fournier, M.L.; Aussudre, J.; Sicard, P.; Obenaus, A.; Marchi, N.; Badaut, J. Early cerebrovascular and long-term neurological modifications ensue following juvenile mild traumatic brain injury in male mice. Neurobiol. Dis. 2020, 141, 104952. [CrossRef]

94. Regensburger, A.P.; Fonteyne, L.M.; Jungert, J.; Wagner, A.L.; Gerhalter, T.; Nagel, A.M.; Heiss, R.; Flenkenthaler, F.; Qurashi, M.; Neurath, M.F.; et al. Detection of collagens by multispectral optoacoustic tomography as an imaging biomarker for Duchenne muscular dystrophy. Nat. Med. 2019, 25, 1905-1915. [CrossRef]

95. Buehler, A.; Herzog, E.; Razansky, D.; Ntziachristos, V. Video rate optoacoustic tomography of mouse kidney perfusion. Opt. Lett. 2010, 35, 2475-2477. [CrossRef] [PubMed]

96. Pan, W.; Peng, W.; Ning, F.; Zhang, Y.; Wang, Y.; Xie, W.; Zhang, J.; Xin, H.; Li, C.; Zhang, X. Non-invasive detection of the early phase of kidney injury by photoacoustic/computed tomography imaging. Nanotechnology 2018, 29, 265101. [CrossRef] [PubMed]

97. Hysi, E.; He, X.; Fadhel, M.N.; Zhang, T.; Krizova, A.; Ordon, M.; Farcas, M.; Pace, K.T.; Mintsopoulos, V.; Lee, W.L.; et al. Photoacoustic imaging of kidney fibrosis for assessing pretransplant organ quality. JCI Insight 2020, 5. [CrossRef]

98. Lawrence, D.J.; Escott, M.E.; Myers, L.; Intapad, S.; Lindsey, S.H.; Bayer, C.L. Spectral photoacoustic imaging to estimate in vivo placental oxygenation during preeclampsia. Sci. Rep. 2019, 9, 558. [CrossRef] [PubMed]

99. Yamaleyeva, L.M.; Brosnihan, K.B.; Smith, L.M.; Sun, Y. Preclinical Ultrasound-Guided Photoacoustic Imaging of the Placenta in Normal and Pathologic Pregnancy. Mol. Imaging 2018, 17, 1536012118802721. [CrossRef]

100. Huda, K.; Wu, C.; Sider, J.G.; Bayer, C.L. Spherical-view photoacoustic tomography for monitoring in vivo placental function. Photoacoustics 2020, 20, 100209. [CrossRef]

101. Hacker, L.; Brunker, J.; Smith, E.S.J.; Quiros-Gonzalez, I.; Bohndiek, S.E. Photoacoustics resolves species-specific differences in hemoglobin concentration and oxygenation. J. Biomed. Opt. 2020, 25. [CrossRef]

102. Laufer, J.; Elwell, C.; Delpy, D.; Beard, P. In vitro measurements of absolute blood oxygen saturation using pulsed near-infrared photoacoustic spectroscopy: Accuracy and resolution. Phys. Med. Biol. 2005, 50, 4409-4428. [CrossRef]

103. Laufer, J.; Delpy, D.; Elwell, C.; Beard, P. Quantitative spatially resolved measurement of tissue chromophore concentrations using photoacoustic spectroscopy: Application to the measurement of blood oxygenation and haemoglobin concentration. Phys. Med. Biol. 2007, 52, 141-168. [CrossRef] [PubMed] 
104. David, H.; Ughetto, A.; Gaudard, P.; Plawecki, M.; Paiyabhroma, N.; Zub, E.; Colson, P.; Richard, S.; Marchi, N.; Sicard, P. Experimental Myocardial Infarction Elicits Time-Dependent Patterns of Vascular Hypoxia in Peripheral Organs and in the Brain. Front. Cardiovasc. Med. 2020, 7, 615507. [CrossRef]

105. Brown, E.; Brunker, J.; Bohndiek, S.E. Photoacoustic imaging as a tool to probe the tumour microenvironment. Dis. Models Mech. 2019, 12. [CrossRef]

106. Galanzha, E.I.; Zharov, V.P. In vivo photoacoustic and photothermal cytometry for monitoring multiple blood rheology parameters. Cytom. A 2011, 79, 746-757. [CrossRef]

107. Van den Berg, P.J.; Daoudi, K.; Steenbergen, W. Review of photoacoustic flow imaging: Its current state and its promises. Photoacoustics 2015, 3, 89-99. [CrossRef]

108. Brunker, J.; Beard, P. Velocity measurements in whole blood using acoustic resolution photoacoustic Doppler. Biomed. Opt. Express 2016, 7, 2789-2806. [CrossRef]

109. Zharov, V.P.; Galanzha, E.I.; Shashkov, E.V.; Kim, J.W.; Khlebtsov, N.G.; Tuchin, V.V. Photoacoustic flow cytometry: Principle and application for real-time detection of circulating single nanoparticles, pathogens, and contrast dyes in vivo. J. Biomed. Opt. 2007, 12, 051503. [CrossRef]

110. Cai, C.; Carey, K.A.; Nedosekin, D.A.; Menyaev, Y.A.; Sarimollaoglu, M.; Galanzha, E.I.; Stumhofer, J.S.; Zharov, V.P. In vivo photoacoustic flow cytometry for early malaria diagnosis. Cytom. A 2016, 89, 531-542. [CrossRef]

111. Hansson, G.K. Inflammation, atherosclerosis, and coronary artery disease. N. Engl. J. Med. 2005, 352, 1685-1695. [CrossRef]

112. Stary, H.C.; Chandler, A.B.; Dinsmore, R.E.; Fuster, V.; Glagov, S.; Insull, W., Jr.; Rosenfeld, M.E.; Schwartz, C.J.; Wagner, W.D.; Wissler, R.W. A definition of advanced types of atherosclerotic lesions and a histological classification of atherosclerosis. A report from the Committee on Vascular Lesions of the Council on Arteriosclerosis, American Heart Association. Arter. Thromb. Vasc. Biol. 1995, 15, 1512-1531. [CrossRef]

113. Park, Y.M. CD36, a scavenger receptor implicated in atherosclerosis. Exp. Mol. Med. 2014, 46, e99. [CrossRef]

114. Mahmood, S.S.; Levy, D.; Vasan, R.S.; Wang, T.J. The Framingham Heart Study and the epidemiology of cardiovascular disease: A historical perspective. Lancet 2014, 383, 999-1008. [CrossRef]

115. Bi, R.; Dinish, U.S.; Goh, C.C.; Imai, T.; Moothanchery, M.; Li, X.; Kim, J.Y.; Jeon, S.; Pu, Y.; Kim, C.; et al. In vivo label-free functional photoacoustic monitoring of ischemic reperfusion. J. Biophotonics 2019, 12, e201800454. [CrossRef]

116. Moustakidis, S.; Omar, M.; Aguirre, J.; Mohajerani, P.; Ntziachristos, V. Fully automated identification of skin morphology in raster-scan optoacoustic mesoscopy using artificial intelligence. Med. Phys. 2019, 46, 4046-4056. [CrossRef]

117. Schwarz, M.; Buehler, A.; Aguirre, J.; Ntziachristos, V. Three-dimensional multispectral optoacoustic mesoscopy reveals melanin and blood oxygenation in human skin in vivo. J. Biophotonics 2016, 9, 55-60. [CrossRef] [PubMed]

118. Wang, Y.; Zhan, Y.; Harris, L.M.; Khan, S.; Xia, J. A portable three-dimensional photoacoustic tomography system for imaging of chronic foot ulcers. Quant. Imaging Med. Surg. 2019, 9, 799-806. [CrossRef] [PubMed]

119. Hariri, A.; Chen, F.; Moore, C.; Jokerst, J.V. Noninvasive staging of pressure ulcers using photoacoustic imaging. Wound Repair Regen. 2019, 27, 488-496. [CrossRef]

120. Wu, Z.; Duan, F.; Zhang, J.; Li, S.; Ma, H.; Nie, L. In vivo dual-scale photoacoustic surveillance and assessment of burn healing. Biomed. Opt. Express 2019, 10, 3425-3433. [CrossRef]

121. Liu, Y.; Fu, L.; Xu, M.; Zheng, J.; Yuan, Z. Dual-Modal In Vivo Fluorescence/Photoacoustic Microscopy Imaging of Inflammation Induced by GFP-Expressing Bacteria. Sensors 2019, 19, 238. [CrossRef]

122. Bhutiani, N.; Grizzle, W.E.; Galandiuk, S.; Otali, D.; Dryden, G.W.; Egilmez, N.K.; McNally, L.R. Noninvasive Imaging of Colitis Using Multispectral Optoacoustic Tomography. J. Nucl. Med. 2017, 58, 1009-1012. [CrossRef] [PubMed]

123. Atreya, R.; Neumann, H.; Neufert, C.; Waldner, M.J.; Billmeier, U.; Zopf, Y.; Willma, M.; App, C.; Munster, T.; Kessler, H.; et al In vivo imaging using fluorescent antibodies to tumor necrosis factor predicts therapeutic response in Crohn's disease. Nat. Med. 2014, 20, 313-318. [CrossRef] [PubMed]

124. Rath, T.; Bojarski, C.; Neurath, M.F.; Atreya, R. Molecular imaging of mucosal alpha4beta7 integrin expression with the fluorescent anti-adhesion antibody vedolizumab in Crohn's disease. Gastrointest. Endosc. 2017, 86, 406-408. [CrossRef]

125. Shen, B.; Kochhar, G.; Navaneethan, U.; Farraye, F.A.; Schwartz, D.A.; Iacucci, M.; Bernstein, C.N.; Dryden, G.; Cross, R.; Bruining, D.H.; et al. Practical guidelines on endoscopic treatment for Crohn's disease strictures: A consensus statement from the Global Interventional Inflammatory Bowel Disease Group. Lancet Gastroenterol. Hepatol. 2020, 5, 393-405. [CrossRef]

126. Crespi, M.; Dulbecco, P.; De Ceglie, A.; Conio, M. Strictures in Crohn's Disease: From Pathophysiology to Treatment. Dig. Dis. Sci. 2020, 65, 1904-1916. [CrossRef]

127. Lei, H.; Johnson, L.A.; Eaton, K.A.; Liu, S.; Ni, J.; Wang, X.; Higgins, P.D.R.; Xu, G. Characterizing intestinal strictures of Crohn's disease. Biomed. Opt. Express 2019, 10, 2542-2555. [CrossRef] [PubMed]

128. Bettenworth, D.; Bokemeyer, A.; Baker, M.; Mao, R.; Parker, C.E.; Nguyen, T.; Ma, C.; Panes, J.; Rimola, J.; Fletcher, J.G.; et al. Assessment of Crohn's disease-associated small bowel strictures and fibrosis on cross-sectional imaging: A systematic review. Gut 2019, 68, 1115-1126. [CrossRef]

129. Knieling, F.; Gonzales Menezes, J.; Claussen, J.; Schwarz, M.; Neufert, C.; Fahlbusch, F.B.; Rath, T.; Thoma, O.M.; Kramer, V.; Menchicchi, B.; et al. Raster-Scanning Optoacoustic Mesoscopy for Gastrointestinal Imaging at High Resolution. Gastroenterology 2018, 154, 807-809.e803. [CrossRef] 
130. Heichler, C.; Scheibe, K.; Schmied, A.; Geppert, C.I.; Schmid, B.; Wirtz, S.; Thoma, O.M.; Kramer, V.; Waldner, M.J.; Büttner, C.; et al. STAT3 activation through IL-6/IL-11 in cancer-associated fibroblasts promotes colorectal tumour development and correlates with poor prognosis. Gut 2020, 69, 1269-1282. [CrossRef] [PubMed]

131. Regensburger, A.P.; Wagner, A.L.; Claussen, J.; Waldner, M.J.; Knieling, F. Shedding light on pediatric diseases: Multispectral optoacoustic tomography at the doorway to clinical applications. Mol. Cell. Pediatr. 2020, 7, 3. [CrossRef]

132. McInnes, I.B.; Schett, G. The pathogenesis of rheumatoid arthritis. N. Engl. J. Med. 2011, 365, 2205-2219. [CrossRef] [PubMed]

133. McInnes, I.B.; Schett, G. Pathogenetic insights from the treatment of rheumatoid arthritis. Lancet 2017, 389, 2328-2337. [CrossRef]

134. Razansky, D.; Klohs, J.; Ni, R. Multi-scale optoacoustic molecular imaging of brain diseases. Eur. J. Nucl. Med. Mol. Imaging 2021. [CrossRef]

135. Kang, N.Y.; Park, S.J.; Ang, X.W.; Samanta, A.; Driessen, W.H.; Ntziachristos, V.; Vasquez, K.O.; Peterson, J.D.; Yun, S.W.; Chang, Y.T. A macrophage uptaking near-infrared chemical probe CDnir7 for in vivo imaging of inflammation. Chem. Commun. 2014, 50, 6589-6591. [CrossRef] [PubMed]

136. Wagner, A.L.; Danko, V.; Federle, A.; Klett, D.; Simon, D.; Heiss, R.; Jungert, J.; Uder, M.; Schett, G.; Neurath, M.F.; et al. Precision of handheld multispectral optoacoustic tomography for muscle imaging. Photoacoustics 2021, 21, 100220. [CrossRef]

137. Noris, M.; Perico, N.; Remuzzi, G. Mechanisms of disease: Pre-eclampsia. Nat. Clin. Pract. Nephrol. 2005, 1, 98-114, quiz 120. [CrossRef] [PubMed]

138. Brochu, F.M.; Brunker, J.; Joseph, J.; Tomaszewski, M.R.; Morscher, S.; Bohndiek, S.E. Towards Quantitative Evaluation of Tissue Absorption Coefficients Using Light Fluence Correction in Optoacoustic Tomography. IEEE Trans. Med. Imaging 2017, 36, 322-331. [CrossRef]

139. Joseph, J.; Tomaszewski, M.R.; Quiros-Gonzalez, I.; Weber, J.; Brunker, J.; Bohndiek, S.E. Evaluation of Precision in Optoacoustic Tomography for Preclinical Imaging in Living Subjects. J. Nucl. Med. 2017, 58, 807-814. [CrossRef] [PubMed]

140. Bohndiek, S. Addressing photoacoustics standards. Nat. Photonics 2019, 13, 298. [CrossRef]

141. Mercep, E.; Jeng, G.; Morscher, S.; Li, P.C.; Razansky, D. Hybrid optoacoustic tomography and pulse-echo ultrasonography using concave arrays. IEEE Trans. Ultrason. Ferroelectr. Freq. Control 2015, 62, 1651-1661. [CrossRef]

142. Mercep, E.; Dean-Ben, X.L.; Razansky, D. Combined Pulse-Echo Ultrasound and Multispectral Optoacoustic Tomography With a Multi-Segment Detector Array. IEEE Trans. Med. Imaging 2017, 36, 2129-2137. [CrossRef] [PubMed]

143. Rogosnitzky, M.; Branch, S. Gadolinium-based contrast agent toxicity: A review of known and proposed mechanisms. Biometals 2016, 29, 365-376. [CrossRef]

144. Conjusteau, A.; Liopo, A.; Tsyboulski, D.; Ermilov, S.; Elliott, W.; Barsalou, N.; Maswadi, S.; Glickman, R.; Oraevsky, A. Optoacoustic Sensor for Nanoparticle Linked Immunosorbent Assay (NanoLISA); SPIE: Bellingham, WA, USA, 2011 ; Volume 7899.

145. Longo, D.L.; Stefania, R.; Aime, S.; Oraevsky, A. Melanin-Based Contrast Agents for Biomedical Optoacoustic Imaging and Theranostic Applications. Int. J. Mol. Sci. 2017, 18, 1719. [CrossRef]

146. Liopo, A.; Oraevsky, A. Nanoparticles as Contrast Agents for Optoacoustic Imaging. In Nanotechnology for Biomedical Imaging and Diagnostics: From Nanoparticle Design to Clinical Applications; John Wiley \& Sons: Hoboken, NJ, USA, 2015; pp. 111-149. [CrossRef]

147. Hannah, A.; Luke, G.; Wilson, K.; Homan, K.; Emelianov, S. Indocyanine green-loaded photoacoustic nanodroplets: Dual contrast nanoconstructs for enhanced photoacoustic and ultrasound imaging. ACS Nano 2014, 8, 250-259. [CrossRef]

148. Jokerst, J.V.; Van de Sompel, D.; Bohndiek, S.E.; Gambhir, S.S. Cellulose Nanoparticles are a Biodegradable Photoacoustic Contrast Agent for Use in Living Mice. Photoacoustics 2014, 2, 119-127. [CrossRef] [PubMed] 